\title{
THE INFLUENCE OF THREE MEN IN EDNA PONTELLIER'S LIFE IN THE AWAKENING BY KATE CHOPIN: A Psychoanalytic Study
}

\author{
Ratna Asmarani \\ Faculty of Humanities- Diponegoro University - Indonesia \\ ratna_asmarani@yahoo.com
}

\begin{abstract}
This paper focuses on the life of Edna Pontellier, the female main character in Kate Chopin's The Awakening. The purpose is to analyse the influence of the three men in Edna Pontellier's life. The analysis is done using the concept of id, ego, and superego from Freudian psychoanalysis. The result shows that the first man in Edna Pontellier's life, Mr. Pontellier/her husband, serves as the superego that always directs Edna's ego. The second man, Robert Lebrun, is her lover who encourages her to win back her ego which makes her able to begin resisting the superego's demands. The third man, Alcee Arobin, is the woman-seducer who arouses and fullfils her id in the form of sexual desires which has been repressed so far. However, the psychologic al conflicts that she has to endure lead to her decision to end her own life in her own way.
\end{abstract}

Key words: id, ego, superego, Freudian psychoanalysis

\section{Introduction}

Kate Chopin's novel The Awakening (1851-1904) was a controversial novel at its time because it revealed things that were still considered taboo for women to think or do at the time. This novel focuses on the life journey of a woman from the period before marriage, after marriage and after her divorce. In Edna's life, the first name of the female main character, three men appear, each of whom has an influence on the development of her personality. The purpose of this paper is to analyze Edna's relationship with the three men in her life to explore the influence of each man in the development of his personality. For this reason, Freud's psychoanalytic theory is used with a focus on the three main systems of personality, namely the id, ego, and superego.

\section{Previous Study}

As Kate Chopin's The Awakening is a famous novel, there are inevitably many articles on this novels. Since it will take pages to list the published articles on The Awakening. Browsing the published articles, it is found out that some of the articles published since 2000 discuss the following topics: "Reading Beyond Modern Feminism (Williams, 2008), "Struggle Against Society and Nature" (Kaplon, 2012), "The Masculine Sea" (Abbasi, 2021), "Self-awareness \& Suicide" (Sherdianti, 2015), "Loss of Self " (Yemez, 2013), "Female Mental Illness" (Collman, 2016) "The Feminist Characters (Nur, 2017), "Pleasure as a Path to Freedom" (Watkins, 2020). In short, it can be said that no article has discussed the role of the three men in developing Edna Pontellier's personality during her life time which become the main topic of this article.

\section{Theory}

Sigmund Freud (1856-1939) divided the human personality into three main systems, namely the id, ego, and 
superego which, if working together in harmony, would produce a healthy personality.

\section{Id}

The id is the main system of personality that is present from birth. This id adheres to the "pleasure principle", which is a basic and main principle of life whose purpose is to eliminate or reduce tension. The tension that arises in human life will cause discomfort and pain and when this tension is reduced there will be a sense of comfort and satisfaction. Tension, such as hunger and thirst, can be reduced or eliminated by "impulsive motor activity" where objects of hunger and thirst can be obtained. If you cannot get a real fulfillment object, a "wish-fulfillment" will emerge, namely the formation of an image of an object that can reduce tension, for example by imagining/dreaming about the object desired by the id. Briefly, it can be summarized that the characteristics of the id are as follows: "The id does not change with the passage of time ... The id is not governed by laws of reason or logic, and it does not possess values, ethics, or morality ... It is demanding, impulsive, irrational, asocial, selfish, and pleasure-loving" (Hall, 1956: 26-27; see also Freud, 1960: 19, Mollinger, 1981: 5, Bateman \& Holmes, 1995: 35, Petocz, 1999: 146, Rennison, 2001: 87, Roth, 2001: 11-12, Wright, 1984: $62)$.

\section{Ego}

Two ways the id takes to reduce tension, namely getting the object needed impulsively and imagining it does not always satisfy the id, it may even reap the dangers and punishments that will lead to new tension (Hall, 1956: 27-28). In dealing with the outside world (which the id cannot do well) requires the formation of a different psychological system called the ego. If the id adheres to the "pleasure principle", then the ego adheres to the "reality principle" which can be briefly explained as follows: "The aim of the reality principle is to postpone the discharge of energy until the actual object that will satisfy the need has been discovered or produced" (Hall, 1956: 28; see also Freud, 1960: 20, Mollinger, 1981: 5, Bateman \& Holmes, 1995: 36-37, Petocz, 1999: 146, Rennison, 2001: 85, Roth, 2001: 12, Wright, 1984: 62).

Adhering to the "reality principle", the ego can be said as follows:

In the well-adjusted person the ego is the executive of the personality, controlling and governing the id and the superego and maintaining commerce with the external world in the interest of the totaloersonality and its far-flung needs. When the ego is performing its executive function wisely, harmony and adjustment prevail ... The ego may be thought of as a complex organization of psychological processes that acts as an intermediary between the id and the external world (Hall, 1956: 28, 30).

In addition, if the id produces images of desired objects that are not/have not been fulfilled, then the ego also produces fantasies and dreams. However, in the id, the image and the desired object are still united, while the fantasy ego that is formed is never equated with the real object (Hall, 1956: 30).

\section{Superego}

If the id adheres to the "pleasure principle" and the ego adheres to the "reality principle", then the superego can be said to adhere to the "morality principle" because basically the superego is "the moral or judicial branch of personality" (Hall, 1956: 31). With its "morality principle", the superego is: "represents the ideal rather than the real .... The superego is the person's moral code. It develops out 
of the ego ... the superego enforces its rules by rewards and punishments. These rewards and punishments are conferred upon the ego ... The ego may be rewarded or punished for merely thinking of doing something" (Hall, 1956: 31-32; see also Freud, 1960: 55, Mollinger, 1981: 5, Bateman \& Holmes, 1995: 35, Petocz, 1999: 153, Rennison, 2001: 89, Roth, 2001: 19-20, Wright, 1984: 62).

Thus in brief it can be said that the id, ego, and superego are the three main systems of personality according to Freud which have different functions. However, the three of them are not mutually exclusive but are interrelated in the process. The id, which is an innate instinct, creates the ego in the process, while the ego forms the superego so that the ego can be said to be the mediator who reconciles the demands of id satisfaction and the pressure of superego morality.

\section{Method}

The analysis applies library research method and close reading method to collect and scrutinize the data from the supporting theories and the literary work analyzed. Then the data is analyzed using qualitative method. For the literary analysis, it applies textual method enriched by relevant context bearing in mind Beard statement "Context refers to what goes with a text, rather than what is in it" (2001: 6). The textual method focusses on the intrinsic elements especially characters, conflict, and setting while the enriching contexts is supported by Freud's psychoanalysis especially on id, ego, superego.

\section{Results and Discussion}

\section{The Relationship of Edna and Mr Pontellier}

Edna is the wife of Mr. Pontellier, a Creole who become a successful businessman. Edna herself is an American who grew up on a plantation in Kentucky. Her mother is dead so she is under the care of a military father and a very practicalminded older sister. Edna grows into an independent figure (Chopin, 1976: 6, 17-18, 68). Edna is a closed person and has "dual life - that is, outward existence which conforms, the inward life which questions" (Chopin, 1976: 15). In other words, Edna is secretly perceptive and critical even though her criticism is not overtly shown in her daily interactions. In addition, before marriage, Edna had a rebellious nature, liked to explore her surroundings alone, as well as filled with romantic dreams. Edna's rebellious nature appeared when she often ran away from prayer meetings at the house led by her strict father and when she was opposed to marrying Mr. Pontellier it made her more desperate to marry Mr. Pontellier (Chopin, 1976: 17-19). Her exploring nature can be seen when she always enjoys walking alone across plantations and vast grasslands (Chopin, 1976: 17). Meanwhile, her romantic nature appeared in the hidden feelings of falling in love with a sad-eyed cavalry member, her neighbor fiancés, and with a tragedian actor whom all did not know her (Chopin, 1976: 18-19). All of these are Edna's unique characters before she marries Mr Pontellier. In other words, Edna already had a personal ego before she marries Mr. Pontellier. Her ego is formed because of the environment she was raised in.

After marrying Mr. Pontellier and moving into the stately, luxurious, and spacious New Orleans home with several helpers, Edna's life changed completely. $\mathrm{Mr}$ Pontellier leads a traditional married life. He acts as a breadwinner for the family and Edna is positioned in the role of a housewife who takes care of children and the household: "a mother's place to look after the children ... He himself had his hands full with his brokerage business. He could not be 
in two places at once; making a living for his family on the street, and staying at home to see that no harm befell them" (Chopin, 1976: 7). As the head of the household, Mr. Pontellier does not hesitate to "reproached his wife with her attention, her habitual neglect of the children" (Chopin, 1976: 7) when she is considered to have neglected her obligations as a mother so that she did not know that one of their children had a fever. Mr. Pontellier also makes Edna carry out social activities for the Pontellier family. As a respected family, Mr. Pontellier strictly follows the social custom of the respectable families, which is to entertain guests in their house on certain days, which for the Pontellier family it is on Tuesdays. On that occasion Edna has to be at home, looking good and being an elegant hostess welcoming and entertaining guests while Mr. Pontellier is busy working. This is the social role that Edna has played well for years. When Edna neglected this task and the reasons put forward are completely incomprehensible to $\mathrm{Mr}$. Pontellier, $\mathrm{Mr}$. Pontellier is very angry because he is the type of person who is very obedient and disciplined in following social customs and norms (Chopin, 1976: 50-51). This incident clearly shows who is in charge and who must obey the rules in the marriage life of Edna-Mr. Pontellier.

Mr. Pontellier adores his wife very much. For Mr. Pontellier, Edna, his wife, is "the sole object of his existence" (Chopin, 1976: 7) and he views Edna as "a valuable piece of personal property" (Chopin, 1976: 4). In other words, Mr. Pontellier positioned himself as owner and Edna as owned entity. This obviously shows a hierarchical relationship, in which Edna is just an entity that is valuable in the eyes of the husband. Over time, Edna's marriage with $\mathrm{Mr}$. Pontellier gradually changes. The romantic relationship between them begins to fade so that what is left is "She grew fond of her husband ... no trace of passion ... colored her affection" (Chopin, 1976: 18-19). In addition, as husband and wife, they do not have suitable material to discuss in their relationship. All this causes Edna, who is basically critical, to think that her marriage to $\mathrm{Mr}$. Pontellier is "purely an accident ... She fancied there was a sympathy of thought and taste between them, in which fancy she was mistaken" (Chopin, 1976: 19). From this, it can be seen that her marriage to Mr. Pontellier turned Edna, who has a rebellious and romantic spirit, into a domestic and gender-bound figure as a wife and housewife. In other words, Edna's personal and unique ego does not develop because it has no place in their traditional marriage life.

However, this does not mean that Mr. Pontellier is either evil or extremely repressive. Mr. Pontellier is a very generous person and very generous with his money. He often buys gifts and cakes for his wife who is enjoying a vacation in Grand Isle with their children. His attention to his wife and children make Mr. Pontellier very popular and liked by everyone in the Grand Isle: "all declared that Mr. Pontellier was the best husband in the world. Mrs Pontellier was forced to admit that she knew of none better" (Chopin, 1976: 9). In other words, Edna could not help but acknowledge Mr. Pontellier's care and loyalty towards his family. On the other side, Mr. Pontellier tends to judge and give comments that evaluate Edna's activities. For example, when Edna plays in the sea for too long so that her skin is burned, $\mathrm{Mr}$ Pontellier comments as follows: "What folly! to bathe at such hour in such heat!" (Chopin, 1976: 4) or when Edna talks about trivial matters with Robert, Mr. Pontellier considers it a childish activity which he does not understand (Chopin, 1976: 5). Mr. Pontellier also tends to watch over his wife's activities from a distance, not accompany her. This 
can be seen when Edna, who is very happy and tense because she has just been able to swim, sulks to her husband that she could have been hurt, her husband calmly replied: "You were not so very far, my dear; I was watching for you" (Chopin, 1976: 29). Mr. Pontellier's answer is not wrong, but the answer is too straightforward, too distant, and there is an impression that he is more knowledgeable, more experienced, and more alert so that he does not generate the empathy that is much needed by Edna to support her mixed emotions. In other words, although Mr. Pontellier greatly adores his wife and often showers her with gifts, he is not the romantic type. Mr. Pontellier is more likely to be Edna's father or older brother. $\mathrm{Mr}$ Pontellier becomes a patriarchal figure who tends to give an assessment of the gender roles that his wife is positioned. In other words, Mr. Pontellier plays more of a superego role in Edna's life. The superego that acts to control Edna's ego and gives negative comments if Edna's ego is considered not in line with the expectations of the superego. In a relationship like this, it is inevitable that Edna's ego does not develop freely because it is always under such careful control of the dominant superego.

No matter how smooth the superego directs the ego to follow the path that the superego agrees to, one day the ego will also feel disturbed. Likewise with Edna. Edna feels that her husband, who from the perspective of others looks perfect, full of affection, and adores his wife, starts making her uncomfortable and oppressed: "An indescribable oppression, which seemed to generate in some unfamiliar part of her consciousness, filled her whole being with a vague anguish. It was like a shadow, like a mist passing across her soul's summer day. It was strange and unfamiliar, it was a mood" (Chopin, 1976: 8). Edna's disturbed ego begins to perform several reactions as forms of resistance to superego directives that she does not feel appropriate for her.

When Mr. Pontellier rebukes Edna who is judged negligent in taking care of the children, Edna begins to resist. Edna's form of resistance can be classified as passive resistance. Edna keeps silent, refuses to answer her husband's questions, leaves the room, and weeps alone outside the rest house (Chopin, 1976: 7-8). Usually Edna does not react like that when she gets a reprimand from her husband who thinks she does not carry out her gender role properly. Edna's reaction this time shows an explosion of accumulated uncomfortable feelings that have been clinging to her. In other words, all this time Edna's ego has tried to repress the uncomfortable feeling that arises every time there is a clash with her husband's superego, but over time the pile of repressed uncomfortable feelings has reached its culmination point so that it bursts out in the form of passive resistance as described above.

Edna's resistance to the demand of superego takes another form. When Edna begins to feel uncomfortable with the family's social event of entertaining female guests every Tuesday that she has been doing for six years, Edna lightly leaves her duty without official notification or consultation to her husband. Mr. Pontellier rebukes Edna's action because it disappoints the important guests who has arrived and it will not only damage their family's good image but also disrupt Mr. Pontellier's business. Not accepting her husband's anger in silence anymore, a heated argument break out between the two. As a result, $\mathrm{Mr}$ Pontellier leaves the house for his club. Edna's reaction is more complex. Edna eats and continues her dinner calmly and does not feel sad as when she is in conflict with her husband. After that Edna tears the handkerchief, take off and tramples on her wedding ring, and slams the vase (Chopin, 
1976: 50-53). This incident implies some interesting points. First, Edna begins to be critical with her robot-like activities during her six years of marriage. Edna's rebellious spirit emerges again which leads her to abandon the weekly social gathering. Second, Edna is better prepared for the conflict that enables her to finish the dinner in peace. Third, it turns out that Edna still fails to repress the resentment she felt as a result of the conflict. As a result, Edna's resistance tends to be active-aggressive, in order to crack her weaknesses (symbolized by tearing a handkerchief), her marital ties (symbolized by trampling her wedding ring), her being considered as a valuable property (symbolized by smashing a ceramic vase). In other words, Edna's slowly strengthening ego begins to show its reaction in facing the clash with the superego.

Edna also begins to indulge in her desire to paint and she can spend days painting in her studio and does not care about household matters. When Mr. Pontellier rebukes her, Edna still does not care, which makes Mr. Pontellier think: "if his wife were not growing a little unbalanced mentally. He could see plainly that she was not herself. That is, he could not see that see was becoming herself and daily casting aside that fictitious self which we assume like a garment with which to appear before the world" (Chopin, 1976: 57). Apart from showing the strengthening of Edna's ego, what is interesting is that there are two contradictory perspectives here. The first perspective is from $\mathrm{Mr}$. Pontellier which also represents a patriarchal perspective that represents the superego. This perspective considers that Edna is a woman with a nervous breakdown, which from a psychoanalytic perspective is considered a woman's weakness. The second perspective is from the side of Edna or women in general who see this change in Edna's actions as an act of realizing the ego layer by layer. Because the female ego is not understood and considered to have deviated from the path set by the superego, women who are realizing their egos are then labeled as mentally disturbed.

In line with the strengthening of Edna's ego, the realization of her ego is increasingly varied. Edna begins to walk and stop at places she has never visited before, such as a quiet secluded cafe (Chopin, 1976: 103), she chooses new friends who are different from those from Mr. Pontellier's neighborhood (Chopin, 1976: 73-74), or starts to make a living on her own by selling her paintings which begins to gain interest (Chopin, 1976: 79). The peak of Edna's ego realization is when she decides to live totally independent by moving to another house (Chopin, 1976: 79) and plans to support herself and form a new circle of friends. In other words, Edna is trying to break the marriage bond which after having lived in it for six years it gives rise to the uncomfortable feelings she has tried to repress. This personal experience has led to her critical view of marriage, namely that: "a wedding is one of the most lamentable spectacles on earth" (Chopin, 1976: 66) which causes him to refuse to attend her younger sister's wedding even though he has to face conflicts with her husband and father (Chopin, 1976: 71).

Edna's growing resistance does not make her husband remain silent. Feeling that he does not know how to best handle the changes in his wife's behavior and thinking, Mr. Pintellier consults the family doctor, Doctor Mandelet, who is also a close friend of the Pontellier family. Doctor Mandelet is often asked for his suggestions because he has extensive experience besides being interested in studying human's psychology. Mr. Pontellier complains because in addition to Edna's being judged to have increasingly neglected her duties as a housewife, her head is also filled with "the eternal rights of 
women" (Chopin, 1976: 65) even though Edna has never associated with "a circle of pseudo-intellectual women" like what doctor Mandelet presumes (Chopin, 1976: 66). Doctor Mandelet calms Mr. Pontellier by saying that: "Woman, my dear friend, is a very peculiar and delicate organism ... Most women are moody and whimsical. This is some passing whim of your wife, due to some cause or causes which you and I need not try to fathom" (Chopin, 1976: 66). In fact, Doctor Mandelet secretly suspects that there is another man in Edna's life, and this suspicion is strengthened when at a banquet at the Pontellier family home, Edna looks different: "There was no repression in her glance or gesture. She reminded him of some beautiful, sleek animal waking up in the sun" (Chopin, 1976: 70). However, Doctor Mandelet's guess about another man in Edna's life leads to the wrong name, as will be discussed later. There are several interesting things that can be drawn from the above events. Mr Pontellier and doctor Mandelet are a patriarchal duo who attempt to analyze the changing conditions of women. First, women who start thinking critically are considered strange and are suspected of being involved in groups of women who have incorrect thoughts. Second, Doctor Mandelet, as one of the intellectual pillars of patriarchy, feels ignorant about the psychological and emotional condition of women so that he lightly considers the changes that are happening to Edna as just an instant oddity that commonly occurs in women, so there is no need to make men wary. Third, Doctor Mandelet's patriarchal-hierarchical perspective is evident when he likens Edna to being an animal, even though it is describes as an attractive, writhing awake one. Fourth, Doctor Mandelet's allegations about another man who playes a role in Edna's life are true. However, the assumption that this man is Arobin (Chopin,
1976: 71) who is good at seducing women is degrading to Edna because this allegation positions Edna as a sexually oriented woman, whereas Edna's awakening is more related to Ego awakening, not Id awakening. This will be discussed further in the next description.

There is one more interesting thing that emerges from the meeting between doctors Mandelet and Edna; namely, when they argued with each other through stories. Doctor Mandelet tells a story based on a true story about: "the waning of a woman's love, seeking strange, new channels, only to return to its legitimate source after days of fierce unrest" (Chopin, 1976: 70). Edna replies to this story with her own fictional story about: "a woman who paddled away with her lover one night in a piroque and never came back" (Chopin, 1976: 70). Actually Doctor Mandelet's goal, as an agent of patriarchy with his story, is to remind Edna not to take the wrong path and even if she is on the wrong path, there is still an opportunity to return to the path justified by patriarchy. Edna, who is smart, of course immediately understands the purpose of Doctor Mandelet's story. Therefore she composes a story about reckless rebellion against patriarchal norms. However, this story by Edna on the one hand strengthens Doctor Mandelet's suspicion about the sexuality factor in changing Edna's behavior.

Thus, it can be briefly said that in her marriage with Mr. Pontellier, Edna's ego does not have the opportunity to develop because Edna was in a patriarchal environment. Even though this patriarchal environment provided a lot of comfort and security, the superego supported by the patriarchy turns out to make Edna's ego uncomfortable and oppressed. The resistance launched by Edna's ego turned out to face a counter-resistance from the superego side, represented by Mr. Pontellier 
who seeks and receives support from Doctor Mandelet.

\section{The Relationship of Edna and Robert Lebrun}

The previous description explains that Edna's ego does not get a chance to grow under the persuasive supervision under the comfort exercised by the patriarchal superego adopted by Mr. Pontellier. In other words, the growing of Edna's ego so that she dares to put up a resistance that is increasingly real and hard-line, of course, comes from outside the patriarchal household of Mr. Pontellier. The environment that supports Edna's ego growth is the vacation place on Grand Isle that is the favorite of the Creole upper class. At that place Edna meets Robert Lebrun, the son of the resort owner whom every summer vacation helps out at his mother's resort. Robert Lebrun, who is two years younger than Edna, Edna 28 years and Robert 26 years, has different traits and attitudes from Mr. Pontellier. $\mathrm{He}$ is a cheerful figure and really serves the vacationing guests. In addition, Robert is a good listener so that Edna, who tends to be introverted, can freely talk about light things and tells about her childhood in Kentucky. In other words, their light never ends. Robert's patience to accompany Edna to bathe in the sea and try hard to teach Edna how to swim - even though it does not work - makes Edna feel comfortable and accustomed to having Robert beside her. Robert also does not feel tired of encouraging and waiting for Edna, who tries to train her talent for painting (Chopin, 1976: 4-6, 13). All of these make Edna feel like herself and more confident. Robert's presence is nurturing: to foster Edna's spirit of painting, to foster Edna's joy, and to foster Edna's self-confidence.

Set in this relaxed, cheerful, and empowering environment, Edna suddenly overcomes her phobia of swimming. When many people and even children try to teach her to swim, Edna is still scared and cannot swim. However, suddenly, alone, and unexpectedly, Edna walks slowly towards the sea and swims without any help.

But that night she was like the little tottering, stumbling, clutching child, who of a sudden realizes its powers, walks for the first time alone, boldly and with overconfidence. She could have shouted with joy. She did shout for joy, as with a sweeping stroke or two she lifted her body to the surface of the water.

A feeling of exultation overtook her, as if some power of significant import had been given her soul. She grew daring and reckless, overestimating her strength. She w anted to swim far out, where no woman had swum before (Chopin, 1976: 28).

This event is a symbol of Edna's courage and success in overcoming her phobia. Edna's courage and success in overcoming the oppression she tries to suppress. Edna's courage and success frees her ego from the fear that suppresses her. In other words, Edna's success in swimming without anyone's help is a symbol of Edna's ego being free from all the rules that try to bind her subtly and persuasively. This liberated ego quickly gets stronger and stronger because it is in a cultivating environment.

Even though Robert plays a big role in growing Edna's ego so that it makes Edna feel comfortable, it does not mean that Robert's presence always makes Edna feel comfortable. There are certain moments where Edna feels disturbed by his presence. The first uncomfortable feeling is related to one-sided physical closeness. Edna is as American female figure unfamiliar with the physical closeness that is so common among Creole people. Therefore Edna feels uncomfortable when Robert is leaning on her, which is what Robert usually does to other Creole ladies, for example Adele, and 
it is considered a close friendship. Edna brushes aside Robert's body and in the end makes Robert stop this attitude (Chopin, 1976: 13). This also indicates the strength of Edna's ego so that she can reject the treatment she does not like. The second indication of the growing ego is related to the imposition of the will. This happened when Robert slightly forces Edna to swim even though Edna does not feel like swimming. When Edna is unable to refuse Robert's invitation to swim, it makes her feel irritated (Chopin, 1976: 14). This incident shows the conflict between Edna's growing ego and Robert's ego. Edna's ego, although starting to get stronger, is still inferior to Robert's ego and because of that Edna feels uncomfortable. What can be drawn from these two incidents is that even with the person who plays a role in strengthening her ego, namely Robert, Edna can also experience things that disturb her ego, all the more with parties who do not support the growing of Edna's ego.

As the ego gets a nurturing condition and the opportunity to strengthen, Edna begins to realize her ego in that vacation place. For example, Edna begins to learn to separate herself from the group by walking alone when they are returning to the cottages, which is something she has never done before (Chopin, 1976: 29). Edna also begins to learn to follow her own wish, namely to go to Chẻniere Caminada and invites Robert to accompany her (Chopin, 1976: 33.). It is the first time for Edna to invite Robert because usually it is Robert himself, who on his own will, follows Edna everywhere. In addition, Edna also begins to dare to break the habit; that is, due to feeling uncomfortable listening to mass at church she lightly decides to leave the church before the mass is over. She decides to spend time exploring Chẻniere Caminada and when she is tired and relaxed she hitched a ride at the house of a local resident, Robert's friend, who is extraordinarily friendly (Chopin, 1976: 37). These deviations from yearly habit are the realization of a strong ego which makes Edna feel more confident about herself.

The closeness to Robert that makes Edna feel very comfortable because it makes her ego strengthened leads to several consequences that Edna is increasingly aware of. The first is the emergence of "the first-felt throbbing of desire" (Chopin, 1976: 31) which makes Edna begin to see around her from a different perspective and it also makes Edna feel accustomed to having Robert by her side. This feeling of comfort and habit unconsciously creates a deep feeling of emptiness when Robert suddenly decides to leave Grand Isle looking for work in Mexico (Chopin, 1976: 45). Edna's ego becomes swayed as the booster suddenly disappears. In addition, this comfortable closeness with Robert overtime gives rise to flutters of love between the two that Edna openly and courageously acknowledges when they meet again: "“I love you," she whispered, "only you, no one but you. It was you who awoke me last summer out of a life-long, stupid dream"" (Chopin, 1976: 107). This statement, apart from showing Edna's love affirmation, also shows that Robert is the person who plays a big role in awakening Edna's ego, who has been sleeping soundly lulled by patriarchal protection.

Although for a moment Edna's ego is swayed when Robert suddenly "disappeared," this awakened ego refuses to fall back asleep again. Edna tries desperately to maintain her newly growing ego. Edna tries her best to keep the fire of love and hope for Robert alive. In order that the memories of Robert, who is now a booster for her ego, do not fade with time, Edna always tries to find information about and discuss about Robert with the Lebrun family, Robert's mother and younger 
brother, and Miss Reisz, a pianist who understands the love that grows between Edna and Robert (Chopin, 1976: 47, 61, 63). In this way, without Robert's physical presence beside her, Edna is still steadfast in maintaining her ego for: "whatever came, she had resolved never again to belong to another than herself" (Chopin, 1976: 80) and: "began to do as she liked and to feel as she liked" (Chopin, 1976: 57). Therefore, Edna can firmly realize her personal desires which her husband strongly disapproves of and is also able to firmly resist all the husband's attempts to shake her ego as previously described in the section on the relationship between Edna and her husband, Mr. Pontellier.

However, the persistence of Edna's ego at one point reaches a point of vulnerability which also occurs shortly after the ego reaches its peak of strength. This can be seen when Edna meets Robert again and the two of them finally openly admit the feelings of love they have been trying to repress. This openness of Robert's feeling dismisses Edna's doubt about Robert's love for her. The statement of Robert's love made Edna's ego soars high and fully strengthened. However, at this point Robert is not strong. The social, moral, and ethical norms of the superego still grip his ego as implied in his words: "you were not free, you were Leonce Pontellier's wife. I couldn't help loving you if you were ten times his wife; but so long as I went away from you and kept away I could help telling you so" (Chopin, 1976: 106). If at that time Robert's ego still has fragile spaces, this would not be the case with Edna's ego. Her ego is steadfast and she firmly defies the superego in her life: "I am no longer one of Mr. Pontellier's possessions to dispose of or not. I give myself where I choose" (Chopin, 1976: 106-107). The persistence of Edna's ego does not get full support from Robert. At this crucial time Edna is suddenly asked to accompany Adele Ratignolle who is about to give birth and she is forced to leave Robert with his fragile ego.

Being alone to make a crucial decision, Robert with his precarious ego chooses to disappear from Edna's life by leaving the words "I love you. Good by because I love you" on a piece of paper (Chopin, 1976: 111). The departure of Robert and his written words imply that Robert is still unable to ignore his superego which considers that his act of loving Edna is an act that cannot be justified from various prevailing norms. In other words, the superego in Robert is much stronger than his ego, so that no matter how much he loves Edna, he does not have the courage to realize more than just words. Edna accepts Robert's decision, but Edna's ego is deeply hurt and suffers from the fragility of Robert's ego. As a result, Edna chooses to get rid of her growing ego. In the past, her ego, slumbering comfortably under the persuasive protection of patriarchy, is symbolically found by Edna through her success of floating in the sea, now Edna melts his ego by drowning herself in the sea (Chopin, 176: 114). Symbolically Edna's action implies his decision to negate her ego, negate herself, to negate Edna, to return to the egoless state which for Edna is the same as her own death. Edna freely picks up the form of her own death.

Thus, it can be briefly said that the relationship between Edna and Robert Lebrun is a relationship that is empowering. Edna's ego, that does not get the opportunity to develop in the marital relationship with Mr. Pontellier, has the opportunity to develop and strengthen in her friendship with Robert. This is because Robert is not like Mr. Pontellier, who acts as if Edna is his possession and tends to judge Edna's behaviors and thoughts. Robert behaves as a friend who patiently listens to Edna's chatter, provides encouragement when Edna 
becomes interested in painting, and accompanies Edna without words if needed. In other words, Robert lets Edna find herself. Robert encourages Edna to find her repressed ego and helps her strengthen her ego by making her feel comfortable so that she is free to be herself.

\section{The Relationship of Edna dan Alcee Arobin}

The third man in Edna's life is Alcee Arobin. Arobin is a flamboyant male figure who is popular in the entertainment venues, such as horse racing, opera, or other modern clubs (Chopin, 1976: 73). Arobin is also famous for his reputation as an accomplished female seducer and even this reputation also reaches the ears of doctors Mandelet (Chopin, 176: 71) and Adele Ratignolle (Chopin, 1976: 95) who never get along with him. Edna at first meets Arobin at the racetrack when Edna takes her father to watch horse races when his father visited her. Arobin, who never lets go of the beautiful woman he is aiming for, tries his best to be able to approach Edna, whose social environment is higher than his social environment. The opportunity to get to know Edna further emerges when she and several people that Edna's father knows at horse races are invited to dinner by $\mathrm{Mr}$. Pontellier in honor of Edna's father. Edna's loneliness, because her father has returned home and her husband has gone abroad, is skillfully used by Arobin to approach Edna (Chopin, 1976: 71).

There are several tactics that Arobin uses to break into Edna's life. For example, he and Mrs. Highcamp, who are his friends, takes Edna to the racetrack again. Arobin's venture is successful because Edna likes horse racing which reminds her of her childhood in Kentucky. So far, Edna has never visited horse races because Mr. Pontellier does not like these activities (Chopin, 1976: 70). In other words, Edna's visits to horse races, alone or with Arobin, are a manifestation of her resistance to the repression of her pleasures by her husband over the years. However, Edna is less aware of the further impact of the closeness that is formed with Arobin. Arobin also uses other tactics to be as often and as long as possible to be near Edna, for example escorting Edna home and, although not invited to enter, asking permission to enter Edna's house to fill reserves of matches which is not really necessary at that time (Chopin, 1976: 75 ). In addition, Arobin also tries to be enthusiastic with Edna's painting activities, writes letters full of sweet pleading words, helps Edna fix his new home, and accompanies Edna in her new house for a long time (Chopin, 1976: 76, 78, 84, 92) .

Edna is not unaware of Arobin's efforts to approach her. Edna also does everything she can to resist Arobin's intensive approach. For example, Edna drives Arobin away from her house, replies to Arobin's letter in a cold tone, or does not care about Arobin's appearance (Chopin, 1976: 77, 78,85). However, Edna's efforts are unsuccessful because what she faces is Arobin, a champion of seducing and conquering women who will not give up easily with objections. In other words, there is a conflict between egos here, between Edna's ego that does not want to be close to Arobin and Arobin's ego that wants to be closer to Edna. Gradually Edna's ego starts to waver too. The trigger is not single. Edna begins to feel lonely with her solitude. Robert is far away in Mexico, Mr Pontellier is overseas, his children are at $\mathrm{Mr}$ Pontellier's mother's house, her relationship with Adele has started to be distant since she decides to move to another house, while Miss Reisz is also not the type to be sociable. Meanwhile, Arobin, who is observant at seeing Edna's loneliness and solitude, quickly increases his approach. As a female conqueror, Arobin's target is 
Edna's body and sexuality. In the eyes of Arobin, Edna is a body and sexuality that is challenging to conquer.

Edna, who is less alert due to inexperience, slowly enters into the trap of sexual charm that Arobin deliberately arouses. In other words, Edna is no match for Arobin, whose sexual experiences are countless. Arobin, for example, with skill and flexibility, "He stood close to her, and the effrontery in his eyes repelled the old, vanishing self in her, yet drew all her awakening sensuousness. He saw enough in her face to impel him to take her hand and hold it while he said his lingering good night" (Chopin, 1976: 76). From the above quote, it appears that Edna's ego quickly melts under Arobin's gaze full of sexual allure. In line with the melting of Edna's ego is the awakening of Edna's id. Edna's carefully repressed libidinal-sexual drive begins to squirm and it does not escape Arobin's observant eyes. Meanwhile, Edna begins to have inner conflicts:

She felt somewhat like a woman who in a moment of passion is betrayed into an act of infidelity, and realizes the significance of the act without being wholly awakened from its glamour. The thought was passing vaguely through her mind, "What would he think?"

She did not mean her husband, she was thinking of Robert Lebrun. Her husband seemed to her now like a person whom she had married without love as an excuse.

... Alcee Arobin was absolutely nothing to her. Yet his presence, his manners, the warmth of his glances, and above all the touch of his lips upon her hand had acted like a narcotics upon her (Chopin, 1976: 77).

Edna's id, ego, and superego are twisted together. Edna's id strengthens and the person who makes Edna's id wake up is a person who is completely ignored by Edna. Because the person is not taken into account, Edna loses her vigilance so that suddenly a sexual turmoil began to weaken Edna's ego. Edna's ego tries to repress the id's urge again because Edna does not want to tarnish her internal commitment in the form of her love for Robert. Edna's ego still favors the figure of Robert. What is interesting is that the figure of Mr. Pontellier as a husband has been completely erased from Edna's memory so that there is no attachment whatsoever between the conflict that Edna is currently experiencing and $\mathrm{Mr}$. Pontellier, who originally represents the superego in Edna's life.

The presence of Arobin in Edna's life becomes increasingly difficult to refuse because of "appealing to the animalism that stirred impatiently within her" (Chopin, 1976: 78). In other words, Arobin is like a conqueror of Edna's id. In Arobin's power, Edna's sexual turmoil is played. As the controller, Arobin starts toying with Edna;s sexual passion "as he spoke his fingers lightly touched the hair that fell a little over her forehead. She liked the touch of his fingers through her hair, and closed her eyes sensitively" (Chopin, 1976: 82). Under Arobin's shrewd touch of sensuality, Edna looks like a cat that her owner likes to poke around. Arobin is the master alias ruler of Edna's id and it is Arobin who will also fulfill Edna's sexual desire. However, Arobin expertly and deliberately pulls off Edna;s sexual desire which will make the sexual arousal even more intense and difficult for Edna to extinguish.

His eyes were very near. He leaned upon the lounge with an arm extended across her, while the other hand still rested upon her hair. They continued silently to look into each other's eyes. When he leaned forward and kissed her, she clasped her head, holding his lips to hers: "It was the first kiss of her lips to which her nature really responded. It was a flaming torch that kindled desire" (Chopin, 1976: 83). 
At this stage, Edna's id is really awakened and begins to flare up demanding the total fulfilment that Arobin deliberately holds out.

The conflict within Edna starts to emerge again. This time it is more complicated, more overlapping, more mixed but also calming.

Edna cried a little that night after Arobin left her ... an overwhelming feeling of irresponsibility. There was her husband's reproach ... There was Robert's reproach ... Above all, there was understanding ... enabling her to look upon and comprehend the significance of life, that monster made up of beauty and brutality ... there was neither shame nor remorse. There was a dull pang of regret because it was not the kiss of love which had inflamed her ... (Chopin, 1976: 83).

Id, ego, and superego collide with each other. Sexual arousal that is awakened, love that is tried to be maintained, moralsocial-ethical norms that are pushed aside, all fight for positions. Despite the clash, the emergence of these three elements makes Edna a complete human being, a complete woman with sexual passion, an ego wrapped in love and a wary superego. In addition, this clash has made Edna more mature, she can accept the existence of her id. Even so, regrets still arise because it turns out that her id is the first to be fulfilled, not her ego as she has hoped.

Arobin carries out the final noose pull. After gradual physical intimacy - kissing her hands, stroking her hair, kissing her lips - Arobin only has to finish Edna's sexual arousal that he has awakened: "He did not answer, except to continue to caress her. $\mathrm{He}$ did not say good night until she had become supple to his gentle, seductive entreaties" (Chopin, 1976: 92). The Arobin's approach is complete. The fulfillment of Edna's sexual turmoil is also complete.

\section{Conclusions}

Edna Pontellier in her adult life knew three men who have different influences on her existence but also complements her at the same time. The first man in his adult life was Mr. Pontellier who becomes her husband. Mr. Pontellier with his traditional concept of gender role division makes him as the representation of superego in Edna's life. Living under the power of the superego, Edna's ego does not have the opportunity to emerge or develop. As a result, Edna feels uncomfortable and oppressed even though she is in an abundance of luxurious materials and facilities. Conflict after conflict begin to emerge in line with the strengthening of Edna's ego.

The second man in Edna's adult life was Robert Lebrun whom she meets at her summer holiday. The relationship between the two of them is a friendship that tends to grow and respect Edna's existence. Because Robert is not as domineering as $\mathrm{Mr}$. Pontellier, Robert's presence makes Edna's ego grow stronger gradually which makes Edna even stronger to resist things that goes against her ego. Apart from that, Robert's presence emanates buds of love in Edna, which Edna does not experience in her marriage to Mr. Pontellier. A strong ego and a growing love vibrate trigger Edna's decision to be herself.

The third man in Edna's adult life is Alcee Arobin. Alcee Arobin has the role of awakening and fulfilling the needs of Edna's id, who has been carefully repressed. Edna's marriage with Mr. Pontellier and her friendship with Robert still makes Edna's id repressed neatly. In other words, the superego and ego remain so dominant that the id has no chance of arising. The presence of Alcee Arobin with his sexual experiences and deadly seductions make Edna's sexual turmoil escape from the repression and get its fulfilment gradually and completely. The rise of Edna's sexual turmoil creates inner 
conflicts within Edna. The feeling of having betrayed her internal commitment to her love to Robert is much more profound than her moral or ethical guilt. However, the release of Edna's id makes Edna a complete woman, not just a beautiful doll that is the pride of her husband or just an ego power that conflicts with superego boundaries.

\section{References}

Abbasi, P, (2012). The Masculine Sea and the Impossibility of Awakening in Chopin's The Awakening. kata, 14(1), 1-42.

Bateman, Anthony and Holmes, Jeremy. (1995). Introduction to Psychoanalysis. Contemporary theory and practice. London and New York: Routledge.

Beard, Adrian. (2001). Texts and Contexts. Introducing literature and language study. London: Routledge.

Chopin, Kate. (1976). The Awakening. London: W.W. Norton \& Company, Inc.

Collman, Elise M. (2016). The Discourse of Female Mental Illness in Kate Chopin's The Awakening". ETD Archive. 892.

Freud, Sigmund. (1960). The Ego and The Id. Translated by Joan Riviere. New York: W.W. Norton \& Company.

Hall, Calvin S. (1956). A Primer of Freudian Psychology. New York: The New American Library of World Literature, Inc.

Kaplon, Megan P. (2012). Kate Chopin's The Awakening: Struggle Against Society and Nature. Inquiries, VOL. 4 NO. 07 | PG. 1/2 |

Mollinger, Robert N. (1981). Psychoanalysis and Literature. An Introduction. Chicago: Nelson Hall.

Nur, Dedi Rahman. (2017). An Analysis of The Feminist Characters in Kate Chopin's "The Awakening". Journal of English Educators Society, 2 (1), 1-20.

Rennison, Nick. (2001). Freud \& Psychoanalysis. Harpenden, Herts: The Pocket Essential.

Roth, Priscilla. (2001). The Superego. Cambridge: Icon Books Ltd

Sherdianti, I. (2015). Self Awareness that Leads to Edna Pontellier's Egoistic Suicide in Kate Chopin's The Awakening Novel. LANTERN (Journal on English Language, Culture and Literature), vol. 3, no. 4.

Petocz, Agnes. (1999). Freud, Psychoanalysis, and Symbolism. Cambridge: Cambridge University Press.

Watkins, Claire Vaye. (2020). "The Classic Novel That Saw Pleasure as a Path to Freedom".

https://www.nytimes.com/2020/02/0

5/books/review/kate-chopin-the-

awakening.html accessed January 8, 2021.

Williams, Christina R. (2008). Reading Beyond Modern Feminism: Kate Chopin's The Awakening. The Oswald Review: An International Journal of Undergraduate Research and Criticism in the Discipline of English: Vol. 10 : Iss. 1, Article 5.

Wright, Elizabeth. (1984). Psychoanalytic Criticism: Theory and Practice. London \& New York: Routledge

Yemez, Öznur. (2013). Loss of Self and the Struggle for Individuality in Kate Chopin's The Awakening. NALANS, Vol. I / Issue 1. 